\title{
VALIDITY AND RELIABILITY OF PERFORMANCE ASSESSMENT OF ACETIC ACID VISUAL INSPECTION
}

\author{
Tri Hariyati, Zulpan \\ Pascasarjana Universitas Negeri Semarang, Universitas Islam Labuhan Batu \\ Tihariyati94@gmail.com \\ Zulpan200990@gmail.com
}

\begin{abstract}
An assessment of performance that has a high level of validity and reliability is needed, because the assessment technique is said to be valid or whether the assessment can be influenced by the instrument. This study aims to develop performance evaluations for midwifery students in valid and reliable of acetic acid visual inspection. Instrument development refers to the Djemari Mardapi development research model with nine steps of development. The technique of collecting data by interview and observation.

The results of content validity show that 21 items have a value of $>0.3$, the results of reliability based on expert agreement show a value of 0.82 which means that experts agree in assessing. The results of $\mathrm{KMO}$ in the field test obtained values of $0.904 \mathrm{MSA}>0.5$, and Bartlett's test significance was 0,000 so that the instrument items could be analyzed further. There are five factors formed from 21 items available, each item in each factor has a value of loading factor> 0.3 then for Alpha Cronbach's coefficient the value is 0.878 . The results of this study can be used as a reference for making an assessment of the performance of students in midwifery practices in the institution.
\end{abstract}

Keywords: Acetic acid visual inspection, Development, Performance Assessment.

\section{INTRODUCTION}

Based on Minister of Health Regulation No. 29 of 2017 to protect communities from the threat of breast cancer and cervical cancer it is recommended that any women or couples of male sufferers of IMS/ISR are encouraged to conduct an Acetic acid visual inspection or Pap smear examination and Be aware of Clinical Examination. One of the competencies in cancer prevention is Acetic acid visual inspection, so that students of midwifery practice in before entering a field already equipped and provided with the evaluation concerning the practice in examination of Acetic acid visual inspection. Midwifery students ever provided with sheet Checklist to ease in doing practice of Acetic acid visual inspection. Students pitch in to the place before practice, trained skills in laboratory campuses in advance because students can not take care of patients/clients directly before they are declared competent of the laboratory Learning. 
Assessment is a very important process of learning. Assessment instruments that meet the standards, will accurately measure the final results of a learning process, so that student learning outcomes will be detected properly and can be used as material for evaluation of the next learning program (Juniarta, 2016, p.1). This is in line with Wachyudi, Sukestiyarno and Budi Waluya (2014, p.217) Assessment of learning outcomes or performance evaluation is expected to be able to assess the competency of students as a whole. Graduates' competencies that cover affective, cognitive and psychomotor aspects must be developed through learning and assessment processes. Performance appraisal as an assessment carried out by observing the activities of students in doing something, so that performance appraisal is considered more authentic (Rusilowati, 2013, p.18). According to Azwar (2011, p.2) states that a good instrument is an instrument that is able to provide reliable information. Measuring instruments or instruments have certain criteria so that they can be called good or decent instruments. These criteria are valid, reliable, standard, economy and practice.

Regarding the assessment problem, Suyanto in Mulyani (2012, p.265) said that until now education at all levels in the implementation of assessments still prioritized cognitive aspects, while affective aspects were still neglected. To overcome the problems associated with assessment as stated above, it is very important to develop a comprehensive assessment instrument that measures the affective, psychomotor and cognitive domains during and after the learning process. According to Andayani and Mardapi (2012, p. M-1) assessment is the process of forming judgments on the quality and level of achievement or performance of students. Assessment is no longer a separate test and is the culmination of learning, but is seen as an integral part of the learning process.

In realizing students that has good basic competencies, an assessment of performance that has a high level of validity and reliability is needed. If the instrument used does not have a performance aspect that is assessed completely and clearly or does not have the validity of an instrument, as a result the assessment is possible to be subjective, that is depending on the perceptions of the lecturer, whether the student's practice is appropriate or not. Even the assessment is not carried out in stages in accordance with the steps that must be taken to assess the competency of student performance. The reality of the field, the assessment instruments used so far have not been tested for validity and reliability to find out whether the instruments have met good standards or not.

The purpose of this study was to obtain an assessment of the performance of midwifery students in a valid and reliable of acetic acid visual inspection. So that the development of this instrument is expected to be able to conduct a comprehensive assessment and can improve the quality of learning and can be used as a reference to making an assessment of student performance in midwifery practices in the institution. 


\section{RESEARCH METHOD}

This study uses a development research design put forward by the development model of Djemari Mardapi, there is ten steps that must be followed in developing an instrument (Mardapi, 2016, p.132). The development procedure in this study refers to nine of the ten steps to developing Mardapi in 2016 which are modified into three main stages, while the three stages are the preliminary stage, the development phase, and the evaluation phase.

Sources of data onto this study were obtained from preliminary observations, study documents and expert validation data as well as test results in the field. The subjects of this study were students of the Muhammadiyah University of Midwifery Academy, Kudus of Midwifery Academy and STIKES Widya Husada Semarang, which numbered 110 people. The sample selection technique in this study is to use the total sampling technique.

Data collection techniques used were interviews, documentation studies. Instrument review by expert or content validity was analyzed using the Aiken's V formula, empirical validity using exploratory factor analysis, while instrument reliability was based on the agreement to the experts on analysis using Two Way Anava and re-analyzed using the Hoyt formula. Instrument reliability based on field results was analyzed using Cronbach Alpha with the help of SPSS version 16 software.

\section{RESULT AND DISCUSSION \\ Content Validity and Reliability Based on Expert Assessments}

Based on the results of content validation from the four experts, an assessment score was obtained and then the instrument was analyzed using the Aiken's V formula. If the validity coefficient $\geq 0.30$ means the item can be said to be valid (Azwar 2014,p.34). The results of content validity based on expert judgment are presented in Table 1.

The results of the validity test using the Aiken's $\mathrm{V}$ formula show that all 21 points of performance assessed have an Aiken coefficient (>0.30), which means that the assessment of Acetic acid visual inspection has good content validity. After validating the contents of the experts, the results of the next study calculated the level of agreement on the four experts using the inter-rater consistency reliability tests analyzed using a different test of two-factor Anava (two way anava) and then proved by analysis of the Hoyt Formula by calculating the value reliability coefficient. The results of the Two Way Anova analysis are present in Table 1. 
Table 1. The Results Of Calculation Of Reliability Two Way Anova

\section{Tests of Between-Subjects Effects}

Dependent Variable: ratter score

\begin{tabular}{cccc}
\hline Source & $\begin{array}{c}\text { Type III Sum } \\
\text { of Squares }\end{array}$ & Df & $\begin{array}{c}\text { Square } \\
\text { Square }\end{array}$ \\
\hline Appraisers & 2.381 & 3 & .794 \\
Grain & 13.452 & 20 & .673 \\
Appraisers * Grain & 7.119 & 60 & .119 \\
\hline
\end{tabular}

Based on the results of the reliability test carried out through two way ANOVA tests using SPSS 16.0, it shows that the variance between the ratter stated by the Appraisal Mean Square is $\mathrm{S}^{2} \mathrm{r}=0.119$ while the Error variance is stated by the Mean Square $*$ Item $S^{2} \mathrm{~S}=0.673$. The results calculated using the Hoyt formula resulted in a reliability coefficient of 0.82 which means that between the ratter assessing agreement with the suitability of the content and this also indicates that the score given by each ratter is consistent. In line with the research conducted by Astuti, Hari Wibawanto, Khumaedi (2015, p. 114) the results of reliability according to experts showed that for job sheets, the assessment instruments of 22 massage movements and performance assessment instruments showed that there were no significant differences between the five experts in assessing content performance assessment instrument for facial skin care practices.

\section{Construct Validity and Reliability of Acetic acid visual inspection Developed Based on Field Test Results.}

The next step is to conduct the first instrument test of the field, analyzed using Exploratorial factor analysis by looking at the correlation value of each item, from the analysis showing the results of KMO (Kaiser Meyer Olkin Measure)> 0.5 which is equal to 0.628 , then the data already meets the criteria for analysis Furthermore. The results of the analysis in the first field test found 4 items which showed a value of $<0.5$ which did not meet the criteria and could not be analyzed further. Items that have a value of $<0.5$ include points 2 with a value of 0.418 , point 9 with a value of 0.459 , item 12 with a value of 0.358 and item 13 with a value of 0.487 .

The results of the reliability analysis of the first instrument test showed the Alpha coefficient value of $0.628<0.70$ so that it can be said to be unreliable, so that revisions or improvements were then analyzed again in the field II test. After testing the instrument in the first field and doing instrument repairs, the next step is to test the instrument on the second field in a total sample of 110 midwifery students. The results of the analysis of the Instrument Feasibility Test of Tests of field II are presented in Table 2. 
Table 2. Test the feasibility of an instrument on the Test field II

\begin{tabular}{|c|c|c|}
\hline $\begin{array}{l}\text { Kaiser-Meyer-Olkin } \\
\text { Sampling Adequacy }\end{array}$ & of & .904 \\
\hline Bartlett's Test of Sphericity & Sig. & .000 \\
\hline
\end{tabular}

Based on the results of the analysis of the instrument test of the second field, the KMO value was 0.904 with a significance of 0,000 , which means that it met the criteria of $\geq 0.5$, so that all 21 items developed could be analyzed further.

Furthermore, it is necessary to see the results of the anti-Image Matrics analysis to see the correlation between the items in the Anti Image Matrics table, especially at the bottom of Anti Image Correlation, a number of numbers that form diagonals (MSA) marked "a" (diagonal direction from top left to bottom right), there is no correlation indicator below 0.5 , so the results of the analysis of this instrument have met the requirements for factor analysis. The following is an Anti Image Correlation table which can be seen in Table 3. below

Table 3. The Results Of Anti Image Correlation

\begin{tabular}{lll}
\hline No & Item & Anti Image Correlation \\
\hline 1 & Welcome patients by greeting & 0,777 \\
2 & Introduce yourself politely and friendly & 0,779 \\
3 & Ask the patient's bio & 0,974 \\
4 & Ask a history of obstetric history previous screening & 0,936 \\
& tests to Asks & 0,949 \\
5 & Ask the perceived symptoms & 0,962 \\
6 & Ask the main complaint & 0,954 \\
7 & Describe the screening tests of Acetic acid visual & \\
& inspection & 0,951 \\
8 & Explain the procedure in the action to be performed & 0,965 \\
9 & Do Informed consent (consent of patient) & 0,981 \\
10 & Respond to the patient's reactions to a good facial & \\
& expressions & 0,825 \\
11 & Respond to the patient's reactions to the patient eye & \\
& gazing & 0,898 \\
12 & Set up tools & 0,899 \\
13 & Prepare materials & 0,875 \\
14 & Setting up a room that will be used & 0,894 \\
15 & Menyiapakan patients before examination & 0,882 \\
16 & Officers prepare & 0,898 \\
17 & Action inspection of Acetic acid visual inspection & 0,613 \\
18 & Do post inspection action of Acetic acid visual & \\
& inspection & 0,600 \\
19 & Take action systematically & 0,577 \\
20 & Maintain the privacy of the patient & 0,568 \\
21 & Welcomes patients by greeting &
\end{tabular}


Based on Table 3. in the anti image column, it can be seen that the correlation value between items obtained a correlation value $>0.5$, therefore factor analysis can be continued by including all items.

Based on the results of the exploratory factor analysis by looking at the analysis value of Total Variance Explained, there were 11 items included in the factor analysis summarized into five groups of factors by looking at the characteristic value of Eigenvalues> 1. The results of the Total Variance Explained are illustrated with Figure 1. Scree Plots.

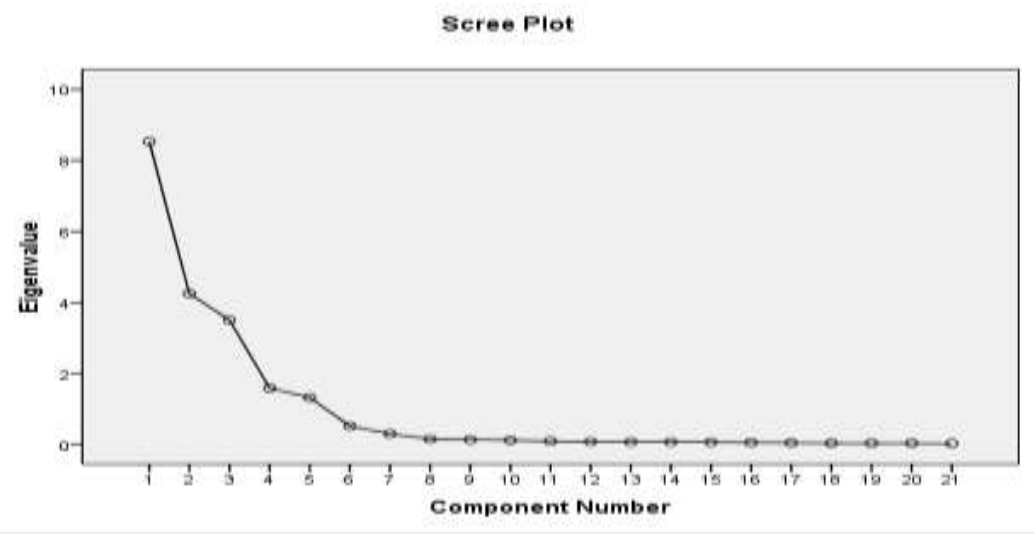

Figure 1. Scree plot

Based on the Scree Plot above, it appears that there are 5 points that are above the value of 1 and the other points are below the value of 1 . This illustrates that there are 5 components that have an eigenvalue value of the value of 1 . Then determining each item will enter into any of the five factors. Grain grouping and the magnitude of loading factors of one factor is seen from the loading factor values which has a value of $>0.3$.

The results of the grouping of 21 items into 5 factors are formed and naming each factor. The components formed in factor 1 are given the name attitude and behavior, the items consist of items 1, 2, 11 and 12. Components formed into factor 2 are given the name of communication, the items consist of items $3,4,5,6,7,8,9$ and 10. The components formed in factor 3 are named preparations, the items consist of items 13, 14, 15, 16 and 17. Components formed into factor 4 are given the name of implementation, items consisting of points 18 and 19. Components formed into factor 5 are given the name of the technique, the items consist of items 20 and 21.

Based on the reliability analysis on the instrument test of the second field conducted through Cronbach Alpha coefficient shows a value of $0.878>0.7$, so it can be said that the assessment of Acetic acid visual inspection examination is consistently used in conducting the assessment. If the value of Cronbach's Alpha is 0.60 and less than 1, then the instrument has a high or reliable correlation, whereas if the value of Cronbach's Alpha is below 0.50 and down, then the instrument is low or unreliable (Basuki and Hariyanto, 2014, p .105). This is in line with the one stated by Naga that the reliability coefficient of 0.50 and above is sufficient to be accepted as good reliability (khumaedi, 2012, p.13).

In line with the research conducted by Suratno, Muhyadi, \& Mardapi (2016, p. 112) that this EFA analysis (Exploratory Factor Analysis) is to test whether a construct can be explained by its indicators. If the indicator can form a construct or variable, then indicated by a high factor 
load (>0.3) means that the measurement is in accordance with the data, and it is expected that the Kaiser-Meyer-Olkin Measure of Sampling (KMO) to value is greater than 0.5. Whereas to check the reliability of an instrument is to look at the Alpha coefficient value of the Cronbach's Alpha formula, which is at least 0.7 as the lowest limit.

\section{CONCLUSIONS}

Based on the results of the research and discussion that has been conducted, it can be concluded that the form of performance assessment of Acetic acid visual inspection developed is in the form of an observation sheet with a number of items of 21, declared valid based on the study of experts obtained values $>0.3$ on each item and obtained the percentage overall feasibility obtained a value of $94 \%$. The test results using exploratory factor analysis obtained KMO value of 0.904 , with the results of this analysis formed into five factors in the performance assessment of Acetic acid visual inspection with Cronbach's Alpha coefficient obtained values $>0.70$, thus it has been obtained a valid and reliable.

\section{REFERENCES}

Ashari, L, Hasan, Lestari W, Hidayah T. 2016. Instrumen Penilaian Unjuk Kerja Siswa SMP Kelas VIII Dengan Model Peer Assessment Berbasis Android Pada Pembelajaran Penjasorkes Dalam Permainan Bola Voli. Journal of Educational Research and Evaluation, 5(1)

Azwar, S. 2011. Reliabilitas dan Validitas.Yogyakarta: Pustaka Pelajar.

Basuki, Ismet, \& Hariyanto. (2014). Asesemen pembelajaran. Bandung: PT. Remaja Rosdakarya.

Juniarta, Aswin Try, M. . W. (2016). Pengembangan Instrumen Penilaian Pengetahuan Mata Pelajaran Pendidikan Jasmani Olahraga Dan Kesehatan (Pjok) Kelas Xi Semester Gasal, 1659-1664.

Khumaedi, M. (2012). Reliabilitas Instrumen Penelitian Pendidikan. Jurnal Pendidikan Teknik Mesin Vol. 12.

Mardapi, D. \& sri andayani. (2012). Sri Andayani-makalah MCDM semnas 2 Juni Sri Andayani PMAT UNY. Prosiding Seminar Nasional Penelitian, Pendidikan Dan Penerapan MIPA, Fakultas MIPA, Universitas Negeri Yogyakarta,.

Mardapi, D. (2016). Pengukuran Penilaian \& Evaluasi Pendidikan. Yogyakarta: Parama Publshing.

Mulyani, E. 2012.Pengembangan Model Penilaian Komprehensif Berbasis Proyek Pendidikan Kewirausahaan Terintegrasi di SMK. Jurnal Penelitian dan Evaluasi UNY.Tahun 16 No. 2. Hal $252-278$.

Nugroho, bagus setyo., djuniadi., \& A, Rusilowati. (2016). Pengembangan Penilaian Kinerja Menggambar Teknik Potongan Di Smk Pada Kurikulum 2013. Journal of Educational Research and Evaluation, 5(1), 1-7.

Permenkes NO 29 tahun 2017. (2017). Perubahan Atas Peraturan Menteri Kesehatan Nomor 34 Tahun 2015 Tentang Penanggulangan Kanker Payudara Dan Kanker Leher Rahim, 140.

Puji Astuti, Widya, Wibawanto, H, \& Khumaedi, M. 2015. Pengembangan Instrumen Penilaian Unjuk Kerja Praktik Perawatan Kulit Wajah Berbasis Kompetensi Di Universitas Negeri Semarang. Journal of Educational Research and Evaluation, 4(2) 
Rusilowati, A. (2013). Pengembangan Instrumen Non-Tes. Makalah. Seminar Nasional Evaluasi Pendidikan Di Universitas Negeri Semarang.

Setiawan, H. (2017). Pengembangan instrumen asesmen autentik kompetensi pada ranah keterampilan untuk pembelajaran tematik di sekolah dasar. Jurnal Pendidikan, 2(7), 874-882.

Suratno, A., Keahlian Teknik Kendaraan Ringan, K., Menengah Kejuruan Negeri, S., Barat, C., \& Teuku Umar No, J. (2016). Pengembangan Instrumen Penilaian Kompetensi Praktikum Engine Siswa Smk Program Keahlian Teknik Otomotif Developing Assessment Instruments in Competence Practice Engine Student in Smk Automotive Engineering Program. Agus Suratno VANOS Journal Of Mechanical Engineering Education, 11(1), 2528-2700.

Wachyudi, ibnu., Sukestiyarno, YL \& Budi Waluya, St. 2014. Pengembangan Instrumen Penilaian Unjuk Kerja Pada Pembelajaran Dengan Model Problem Solving Berbasis Tik. Seminar Nasional Evaluasi Pendidikan Tahun 2014. ISBN 978-602-14215-5-0 